\title{
Assessment of Career Planning as Predictor of Employee Performance: The Role of Perceived Career Opportunity
}

\author{
Abubakar Tabiu*, Abubakar Allumi Nura \\ Faculty of Management Sciences, Usmanu Danfodiyo Univesity, Sokoto, Nigeria \\ *Corresponding author: abubakar.tabiu@udusok.edu.ng
}

Article history: Received 18 March 2019 Received in revised form: 12 February 2020 Accepted: 15 February 2020 Published online: 30 April 2020

\begin{abstract}
Encouraging employees to put more effort towards achieving organizational goals through good career planning practice has been the focus of many studies. Nevertheless, examining the fundamental reasons why and how career planning/development practice predict performance remains unclear. This study, examined the direct and indirect relationships between career planning/development practice with employee performance (task and contextual) through the mediation of perceived career opportunity. Using a cross sectional survey of 265 employees of 27 local governments in North Western Nigeria, the results of Partial Least Square-Structural Equation Modeling (PLS SEM) revealed that career planning practice predicts employee task and contextual performance and perceived career opportunity was found to have mediated the relationships.
\end{abstract}

Keywords: Career planning, Career opportunity, Task performance, Contextual performance, Nigeria.

(C) 2020 Penerbit UTM Press. All rights reserved

\subsection{INTRODUCTION}

Recent changes at the organizational level as a result of factors like globalization, need for competitive advantage, technological advancement etc have forced organizations to recognize the importance of managing people at work, and in particular the proper planning and development of their careers (Antoniu, 2010). It has been an established fact that, people (i.e human resource) are now the most valuable resource in contemporary organizations (Budhathoki, 2004; Gabcanova, 2012). Hence, providing them with proper planning/development couple with long term stable career is considered to be a win-win situation for both organizations and the employees (Patrick \& Kumar, 2011). Career planning practice looks beyond the short term but rather at the long-term career effectiveness of employees and the success of the organizational (Decenzo \& Robbins, 2010). In addition, a well designed career planning system enables the organizations to tap the wealth of their in-house talents by matching the skills, knowledge, experience, and aspirations of their employees with the needs and goals of the organization. Moreover, it allowed the organizations to make informed decisions about the compensation and succession planning so as to attract, develop, retain and motivate large number of employees that will form a productive workforce (Kapel \& Shepherd, 2004). It is also posited that career planning/development teach employees on how to work toward attaining their own goals while on the other hand continuing to perform productive work for the organization.

However, despite the importance of career planning in promoting positive performance of employee, yet the performance of Nigerian public sector employees is characterized by several non performance factors like inefficiency and ineffectiveness, poor attitude to work (Suleiman, 2013), that are all related to inadequate HRM practices including career planning practice (Inyang \& Akaegbu, 2014). To address the employee performance problem, several reform/policy measures were initiated and executed by successive government. However, still the desired level of public sector employee performance has not yet been attained especially at the grass-root level like local government areas. The Nigerian local governments are called governments at grass-root because they are closer to the people than states and federal/central government.

Although several studies on the link between career planning/development and employee performance (Akhter, Siddique, \& Alam, 2013; Oduma \& Were, 2014; Tiwari, 2011), revealed positive link, nevertheless, scholar like Alfes, Shantz, Truss, and Soane (2013) argued that further research in this area is needed to unearth the mechanisms through which HRM practices including career planning exert influence upon employee performance. To address this gap, this study proposes the mediation of perceived career opportunity (PCO) on the relationship between career planning/development and employee performance (task and contextual). Based on social exchange theory (Blau, 1964), we argued that presence of good career planning/development practice in an organization will serve as a good signal to the employees that their organization has employee at heart and intend for a long term relationship. This will encourage them to perceived 
more career opportunities for growth and advancement. Therefore, the perception of career opportunity will in turn energize them to exhibit higher task and extra role performance.

\subsection{LITERATURE REVIEW}

\section{Employee Performance}

Employee performance being an important concept in the area of work and organizational psychology was conceptualized in several ways by different scholars. For instance, while some group of scholars like Akhter et al. (2013), Shahzad, Bashir, and Ramay (2008) and Tessema and Soeters (2006) conceptualized it as uni-dimensional construct. On the other hand, another group of scholars (Borman \& Motowidlo, 1993; Borman \& Motowidlo, 1997; Koopmans et al., 2013) argued that employee performance is multi-dimensional construct that comprises task and contextual performance. For the purpose of this study, multi- dimensional operationalization of employee performance that consisted task and contextual performance was employed as it is considered as the comprehensive measurement of performance at individual level. Task performance simply refers to the actions and behaviors of employees that are within their job descriptions (i.e. technical core) and formal organizational reward system (Borman \& Motowidlo, 1993; Motowidlo \& Van Scotter, 1994). Therefore, task performance constitutes the fulfillment of the requirements that are within the contract between the employer/management and employee (Sonnentag, Volmer, \& Spychala, 2008). This implied that task performance comprises employee actions and behaviors that are included in his/her job description. When an employee in organization uses his/her skills or knowledge in providing goods or services by means of organization's "core" technical process, or when the employee accomplished a given task that supported the organization's core function, then such employees(s) have engaged in task performance. On the other hand, contextual performance covers employees activities that are outside their job description (i.e discretionary behaviors), but enhances organizational effectiveness by supporting the organizational, social and psychological environment (Borman \& Motowidlo, 1993). Contextual performance are employees actions and behaviors that are voluntary and in some instances not included in the organizational reward system. Therefore, when employee(s) voluntarily supported or assist coworker in accomplishing task, or act in some ways that supported good working relationship, or even exerted extra efforts to completed assigned duty on time, then such employee had engaged in contextual performance (Van Scotter, 2000).

\section{Career Planning and Employee Performance}

Career planning has been conceptualized from organizational and employee perspective. From the organizational perspective, career planning/development is regarded as an important organizational practice that is concerned with a continuous process that relate to the activities of evaluating the abilities and interests, establishing career goals, and planning developmental activities that relate to employees' and the organizations' future needs (Pynes, 2009). As a HRM practice, career planning/development allows the organizations to balance between the employees preferences and abilities and the requests of the organization (Amin, Ismail, Abdul Rasid, \& Selemani, 2014). Career planning and development practice also aligns the employees' interests and skills with the needs of the organization which in turn leads to enhanced performance (Nwuche \& Awa, 2011). Relatedly, (Zia-ur-Rehman, Faisal, \& Khan, 2015) supported that good career planning/development system in organization allowed employees to develop more skills that are not only important to their own career advancement and development but also useful to the successful attainment of organizational objectives.

Ikechukwu and Paschal (2017) asserted that financing career development programmes in organization(s) coupled with the provision of incentives particularly to those staff that endeavor career development do maintained outstanding performance in the organization(s). Their study revealed that career development boasted the performance of university employees (Ikechukwu \& Paschal 2017). Relatedly, Kakui and Gachunga (2016) asserted that good career planning and development of employees often closes gap(s) between the current and expected performance of employees in organizations. The recent study of Mwashila (2018) revealed that career development practices including career planning, mentoring and career advancement do significantly predict performance of academic staff. Similarly, some previous studies (Akhter et al., 2013; Oduma \& Were, 2014; Saleem \& Amin, 2013; Tiwari, 2011) indicated that career planning positively relates with employee performance arguing that presence of well planned career system in organization serve as a good motivational factor that geared employees toward high performance. These findings suggested that when organizations provides employees with good career planning and development programs and policies they tend to put more efforts in discharging their assigned task and at the same time go extra mile by performing beyond what is required (contextual performance), so as to attain the organizational objectives. . Based on that we hypothesized that:

H1a: $\quad$ Career planning will positively relate with task performance.
H1b: $\quad$ Career planning will positively relate with contextual performance.

\section{Mediation of Perceived Career Opportunity}

Perceived Career Opportunity (PCO) is defined by Kraimer, Seibert, Wayne, Liden, and Bravo (2011) as employees' perception on the degree to which his/her present work assignments (employment) and job opportunities match their goals and career interests are available in their current organization. In organization, HRM practices like career planning/development provide employees with more opportunities to extend their full potential and develop their capabilities in organizations in order to satisfy their needs for personal growth and selfactualization. Kakui and Gachunga (2016) observed that high performing organizations are nowadays increasingly paying more attentions to the validity of their internal career practices and are becoming more vigilant on developing employees' career so as to ensure optimum achievement of their employees' performance both in the present and the future. Oduma and Were (2014) revealed that career planning/development practices like training of employees, career mentoring, job orientation and career advancement had a positive influence on employee performance. Gomez (2014) asserted that perception of career progression/development programs by employees in 
organization can attract job seekers and can help them to remain and give their best to the attainment of organizational goal. In this regard, the employees will develop some sense of loyalty to the organizations that are willing to invest in them. Therefore, if employees perceive that their present organizations do encourages their career development, they are likely to feel more confident with regard to their longterm career path and opportunities (Mugaa, Guyo, \& Odhiambo, 2018). Additionally, most talented and competent employees tend to be more satisfied when they perceived favorable opportunities in their present organization and intend to remain and provide their innovative and creative ideas toward the attainment of desired level of task and contextual performance.

The recent study of Mugaa et al. (2018) revealed that perception of career development/progression enhances productivity, quality and quantity of output, effectiveness and efficiency in organization. Similarly, properly implemented career planning and development practice of the organization(s) attracted and maintained talented staff who have the requited abilities to perform effective and efficient tasks implementation (Mohamad \& Yahya, 2017). Additionally, since career planning programs in organizations are designed to provide opportunities to the employees, it is expected that career planning allowed the employees to perceived more favorable opportunities. Thus, career planning/development practice of organization enable the employees to perceived organizational career opportunities as effort from their organization that will allowed them to attain their career goal. In this regard, Rhoades and Eisenberger (2002) posited that providing employees with potential career opportunities like merit based promotion may indicates high level of concern to such employees and also implied organizational recognition of their contributions. Therefore, in return of this gesture the employees may pay back with high task performance and more contextual performance. Based on this we hypothesize that:

H2a: $\quad$ Perceived career opportunity will mediate the relationship between career planning and task performance.

H2b: Perceived career opportunity will mediate the relationship between career planning and contextual performance.

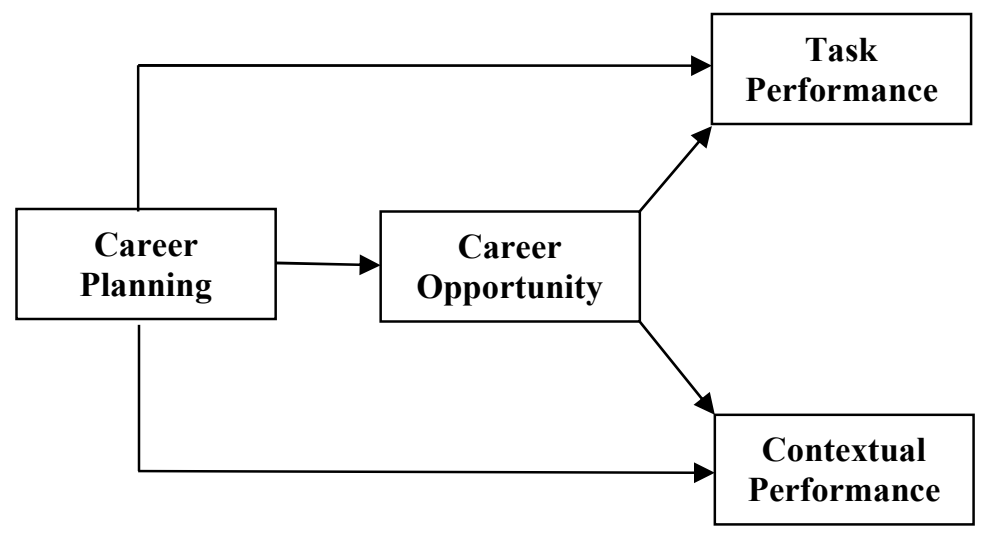

Figure 1 Research Framework

Based on the aforementioned arguments, this study as shown above in Figure 1 (research framework) indicated that career planning can have both direct and indirect relationships with task and contextual performance through the mediation of career opportunity.

\subsection{METHODOLOGY}

Respondents and Procedures

The respondents are senior staff drawn from 27 local government areas of Jigawa state in North western part of Nigeria. Two weeks was given for the completion of the questionnaires. 531 questionnaires were personally distributed by the researchers but only 265 usable questionnaires were returned given a response rate of $50 \%$. The data was collected at point in time as the aim was not to look for changes over time. Therefore, the study used cross sectional design as against longitudinal approach.

\section{Measures}

In measuring all the variables (both dependent and independent and mediating), we adapted items that have been proved to be reliable and validated by previous studies. Career planning: We measured career planning practice with 8-item scale adapted from the work of Amin et al. (2014). Some of the items used include: 'My organization plan for my career \& development as an employee'. For Perceived career opportunity, a three items (3-items) developed and validated by Kraimer et al. (2011) was adapted. Task performance: Was measured with 11-items adapted from the work of Tsui, Pearce, Porter, and Tripoli (1997). Sample of the items include: 'My performance is above average' Contextual performance: Contextual performance was measured with 16-items (though many items were deleted due to poor loadings) developed by Motowidlo and Van Scotter (1994). Sample of the items used include: 'In my organization, I help other my other colleagues to accomplish their work'. The scale of all the response ranged from $1=$ strongly disagree to $5=$ strongly agree. 


\section{Measurement Model}

Results for this study were analyzed using Partial Least Square- Structural Equation Modeling (PLS SEM) through the application of Smart PLS 2.0 software (Ringle, Wende, \& Will, 2005). The Table 1 indicated that all the four latent variables had a composite reliability above the minimum threshold of .70 (Hair, Ringle, \& Sarstedt, 2011; Henseler, Ringle, \& Sinkovics, 2009), and also their Average Variance Extracted (AVE) indicated that the convergent validity of all constructs was above .50 being the threshold. However, items with low loadings were deleted as recommended by scholars.

Table 1 Results of Measurement model

\begin{tabular}{|c|c|c|c|c|}
\hline Latent Constructs & Items & Loadings & CR & AVE \\
\hline \multirow[t]{5}{*}{ Career planning } & CPL02 & 0.740 & 0.866 & 0.564 \\
\hline & CPL03 & 0.752 & & \\
\hline & CPL04 & 0.769 & & \\
\hline & CPL05 & 0.751 & & \\
\hline & CPL07 & 0.743 & & \\
\hline \multirow[t]{3}{*}{ Career opportunity } & COP01 & 0.831 & 0.872 & 0.694 \\
\hline & $\mathrm{COP} 02$ & 0.848 & & \\
\hline & $\mathrm{COP} 03$ & 0.820 & & \\
\hline \multirow[t]{6}{*}{ Task performance } & TSK01 & 0.713 & 0.864 & 0.515 \\
\hline & TSK02 & 0.719 & & \\
\hline & TSK03 & 0.721 & & \\
\hline & TSK04 & 0.717 & & \\
\hline & TSK05 & 0.742 & & \\
\hline & TSK06 & 0.692 & & \\
\hline \multirow[t]{4}{*}{ Contextual performance } & CTX04 & 0.711 & 0.804 & 0.506 \\
\hline & CTX06 & 0.722 & & \\
\hline & CTX14 & 0.679 & & \\
\hline & CTX16 & 0.733 & & \\
\hline
\end{tabular}

Note: $\mathrm{AVE}=$ Average Variance Extracted; $\mathrm{CR}=$ Composite Reliability.

Table 2 depicts that all the four latent construct are distinct as all their squared roots are greater than the correlations among the variables.

Table 2 Result of Discriminant Validity

\begin{tabular}{lcccc}
\hline Latent Constructs & $\mathbf{1}$ & $\mathbf{2}$ & $\mathbf{3}$ & $\mathbf{4}$ \\
\hline Career Opportunity & $\mathbf{0 . 8 3 3}$ & & & \\
Career Planning & 0.671 & $\mathbf{0 . 7 5 1}$ & & \\
Contextual Performance & 0.653 & 0.686 & $\mathbf{0 . 7 1 2}$ & \\
Task Performance & 0.644 & 0.651 & 0.614 & $\mathbf{0 . 7 1 7}$ \\
\hline Note: Bolded values are the squared roots while other values are the correlations among constructs. &
\end{tabular}

\section{Structural Model}

The structural model provides the path coefficient of all the hypotheses. We started by providing the results of the first model which is the direct relationships between the independent variable (career planning/development) and the dependent variables which are the two dimensions of employee performance (task and contextual) without the presence of mediator (perceived career opportunity). Secondly, the full model in which the mediating variable was included was presented as shown in Table 4.

Table 3 Result of Direct Relationships

\begin{tabular}{lcccc}
\hline \multicolumn{1}{c}{ Hypotheses } & Path coefficient & Std. Err & T -value & Decision \\
\hline Career Planning -> Task Performance & 0.651 & 0.044 & $14.674^{* * *}$ & Supported \\
Career Planning $->$ Contextual Performance & 0.686 & 0.049 & $14.041^{* * *}$ & Supported \\
\hline
\end{tabular}


Table 3 above depicts that the relationship between career planning and task performance is significant $(\beta=0.651, p<0.01)$. Similarly, the hypothesized relationship between career planning and contextual performance is also significant $(\beta=0.686, p<0.01)$. Therefore, hypotheses $\mathbf{1 a}$ and $\mathbf{1 b}$ are supported.

Table 4 Mediation Hypotheses Results

\begin{tabular}{|c|c|c|c|c|c|c|}
\hline Endogenous Constructs & & & & & $\mathbf{R}^{2}$ & $\mathbf{Q}^{2}$ \\
\hline Task Performance & & & & & 0.502 & 0.249 \\
\hline Contextual Performance & & & & & 0.538 & 0.260 \\
\hline Perceived Career Opportunity & & & & & 0.450 & 0.298 \\
\hline Relationships & Path $a$ & Path $b$ & $a * b$ & Std. Error & T value & Decision \\
\hline CPL $->$ COP->TSK PERF & 0.670 & 0.399 & 0.268 & 0.056 & $4.809^{* * *}$ & Supported \\
\hline CPL $->$ COP $->$ CTX PERF & 0.670 & 0.450 & 0.302 & 0.053 & $5.693 * * *$ & Supported \\
\hline
\end{tabular}

Table 4 above indicated that perceived career opportunity mediates the relationship between career planning and task performance $(\beta=0.268, p<0.01)$. Likewise, the relationship between career planning and contextual performance is mediated by career opportunity $(\beta=0.302, p<0.01)$. This also proved that hypotheses $\mathbf{2 a}$ and $\mathbf{2 b}$ are empirically supported. Apart from the path coefficient result, the model also recorded higher coefficient of determination popularly called $\mathrm{R}$-square $\left(\mathrm{R}^{2}\right)$. For task performance, the model explained an $\mathrm{R}^{2}$ value of 0.502 , whereas, a value of 0.538 was explained in contextual performance. Additionally, career planning practice explained $\mathrm{R}^{2}$ value of 0.450 for perceived career opportunity. This implied that career planning practice and perceived career opportunity explained $50 \%$ variance in task performance and also about 54\% variance in contextual performance. While, career planning practice alone explained $45 \%$ of the variance in perceived career opportunity. In testing the predictive relevance of our model, blindfolding technique as recommended by scholars (Chin, 1998; Henseler et al., 2009) was employed were a $Q^{2}$ values of 0.298, 0.249 and 0.260 for perceived career opportunity, task performance and contextual performance respectively. These $\mathrm{Q}^{2}$ values which are all greater than zero further substantiated the predictive relevance of the model.

\subsection{DISCUSSION}

The main purpose of this research work was to develop and test a model of how career planning/development influence employee task and contextual performance. Furthermore, the study also concerns with how the relationship between career planning/development and employee performance (task and contextual) is mediated through career opportunity. The results of direct relationship supported that career planning/development influence employee task and contextual performance. This result is consistent with previous studies (Akhter et al., 2013; Oduma \& Were, 2014; Saleem \& Amin, 2013; Tiwari, 2011). This finding also concurred Akhter et al. (2013) arguments that nowadays employees more especially in the public sector are more career conscious and many public sector organizations do provide several career planning practices. Similarly, Irene M. Kakui and Gachunga (2016) observed that high performing organizations are nowadays increasingly paying more attentions to the validity of recruitment practices and are becoming more vigilant on developing employees' career so as to ensure optimum achievement of their employees' performance both in the present and the future. Nevertheless, the results also contradicts some studies (Cho \& Yoon, 2009; Khalid, AbdulRehman, \& Ilyas, 2014). This contradiction can be attributed to the issue of cadre and non cadre difference found in the public sector. For instance, Khalid et al. (2014) observed that career planning in some public organizations particularly in the Asian context the practice in non cadre jobs is however, passive. Therefore, this tends to causes perceptive differences between the cadre and non cadre employees. For instance, Khalid et al. (2014) observed that career planning in some public organizations particularly in the Asian context the career planning practice in non cadre jobs is however, passive. Therefore, this tends to causes perceptive differences between the cadre and non cadre employees.

The significant relationship between career planning/development with employee task and contextual performance suggested that good career planning/development practice allowed the employees to put more effort in discharging assigned task and also go beyond by engaging in positive extra role behaviors that benefits the organization in form of contextual performance. In addition, even though career planning/development was found to have been a good predictor of all the two dimensions of employee performance (task and contextual), our result suggested that the relationship between career planning/development and task performance is stronger than the relationship between career planning/development and contextual performance. This implied that employee prefer to exhibit more task performance rather than more contextual performance when they were contented with their organizational career planning/development practice.

The indirect relationship also established that perceived career opportunity is an important mechanism that accounted for the relationship between career planning/development with employee task and contextual performance. This suggested that good career planning/development practice make employees to perceived developmental career opportunity like promotion opportunity within the organization which in turn influences them to exert higher task and contextual performance. Moreover, the mediation results implied that perception of available career opportunities in organization is the fundamental reason (black box) that explained why and how career planning/development practice influence employee task and contextual performance.

\subsection{CONCLUSION}

Conclusively, previous studies on career planning/development and performance at individual level proved only the direct influence of career planning/development on employee performance, this study extended the extant literature on career planning/development and provides the fundamental reason on how organizational career planning/development practice influences employees task and contextual performance through the mediation of perceived career opportunity. Thus, this study unlike the previous studies provided an empirical 
support that career planning/development exerted significant influence on performance through the mechanism of perceived career opportunity. Therefore, it is clear that good career planning/development practice enables the employees to have positive perception of organizational career opportunities which subsequently move them to exert high task performance and more contextual performance. Therefore, organizations can use career planning/development practice and career opportunities to enhances strong employee task and contextual performance in order to stimulates employees' overall performance. The stimulation of these performances will ultimately enable the organizations to effectively and efficiently achieve overall organizational objectives.

\subsection{LIMITATIONS}

Although this study provided new evidence pertaining to the mediating effect of perceived career opportunity, yet our results should be interpreted against the background of some limitations. Firstly, we used self reporting in all the four constructs. Secondly, we employed cross sectional method which limit conclusion on causal order. Therefore, future study using multiple data source like supervisors, peer/subordinate reporting will minimize common method bias. More importantly, replicating the study using objective measures of performance rather than the subjective might also limit the chances of possible common method biases. Additionally, longitudinal research design can substantiate the causality of our hypotheses.

\section{References}

Akhter, M., Siddique, N., \& Alam, A. (2013). HRM Practices and its Impact on Employee Performance: A Study of the Cement Industry in Bangladesh. Global Disclosure of Economics and Business, 2(2), 125-132.

Alfes, K., Shantz, A., Truss, C., \& Soane, E. (2013). The link Between Perceived Human Resource Management Practices, Engagement And Employee Behaviour: A Moderated Mediation Model. The International Journal of Human Resource Management, 24(2), 330-351.

Amin, M., Ismail, W. K. W., Abdul Rasid, S. Z., \& Selemani, R. D. A. (2014). The Impact Of Human Resource Management Practices On Performance: Evidence from a Public University. The TOM Journal, 26(2), 125-142.

Antoniu, E. (2010). Career Planning Process And Its Role In Human Resource Development. Annals of the University of Petroşani, Economics, 10 (2), 13-22.

Blau, P. M. (1964). Exchange and power in social life. New York: Transaction Publishers.

Borman, W. C., \& Motowidlo, S. (1993). Expanding the Criterion Domain To Include Elements Of Contextual Performance. In N. Schmitt \& W. C. Borman (Eds.), Personnel Selection In Organizations, 71-98. San Francisco: Jossey-Bass.

Borman, W. C., \& Motowidlo, S. J. (1997). Task Performance And Contextual Performance: The Meaning For Personnel Selection Research. Human performance, 10(2), 99-109.

Budhathoki, D. K. (2004). Human Resource Management: Career Development. Journal of Nepalese Business Studies, 1(1), 99-100.

Chin, W. W. (1998). The partial least squares approach to structural equation modeling. In G. A. Marcoulides (Ed.), Modern Methods For Business Research , 295336. Mahwah, New Jersey: Laurence Erlbaum Associates.

Cho, T., \& Yoon, S. (2009). Human Resource Management, Individualism-Collectivism, And Individual Performance Among Public Employees: A Test Of The Main And Moderating Effects. The Korean Journal of Policy Studies, 23(2), 57-78.

Decenzo, D. A., \& Robbins, S. P. (2010). Fundamentals of Human Resource Management. USA: John Wiley \& Sons Inc.

Gabcanova, I. (2012). Human Resources Key Performance Indicators. Journal of Competitiveness, 4(1), 117-128.

Hair, J. F., Ringle, C. M., \& Sarstedt, M. (2011). PLS-SEM: Indeed a Silver Bullet. Journal of Marketing theory and Practice, 19(2), 139-152.

Henseler, J., Ringle, C. M., \& Sinkovics, R. R. (2009). The Use Of Partial Least Squares Path Modeling In International Marketing. Advances in International Marketing, 20(1), 277-319.

Ikechukwu, D., \& Paschal , A. J. N. (2017). Effects of Career Growth On Employees Performance: A Study Of Non-Academic Staff of Michael Okpara University of Agriculture Umudike Abia State, Nigeria. Singaporean Journal Of Business Economics, And Management Studies, 5(7), 8-18.

Inyang, B. J., \& Akaegbu, J. B. (2014). Redefining the Role of the Human Resource Professional (HRP) in the Nigerian Public Service for Enhanced Performance. International Journal of Business Administration, 5(1), 90-98. doi: 10.5430/ijba.v5n1p90

Irene M. Kakui, \& Gachunga, H. (2016). Effects of Career Development On Employee Performance In The Public Sector: A Case Of National Cereals And Produce Board. Strategic Journals Of Business And Change Management, $13(3$ (19)), 307-324.

Kakui, I., \& Gachunga, H. (2016). Effects of Career Development On Employee Performance In The Public Sector: A Case Of National Cereals And Produce Board. Strategic Journal of Business \& Change Management, 3(3), 307-324.

Kapel, C., \& Shepherd, C. (2004). Four Keys To Goals And Performance. Canadian HR Reporter, 17(4), 18

Khalid, M. M., AbdulRehman, C., \& Ilyas, M. (2014). HRM Practices and Employee Performance in Public Sector Organizations in Pakistan: An Empirical study. International Journal of Management Sciences and Business Research, 3(2), 69-77.

Koopmans, L., Bernaards, C., Hildebrandt, V., van Buuren, S., van der Beek, A. J., \& de Vet, H. C. (2013). Development of an individual Work Performance Questionnaire. International Journal of Productivity and Performance Management, 62(1), 6-28.

Kraimer, M. L., Seibert, S. E., Wayne, S. J., Liden, R. C., \& Bravo, J. (2011). Antecedents and Outcomes Of Organizational Support For Development: The Critical Role Of Career Opportunities. Journal of Applied Psychology, 96(3), 485-500.

Mohamad, M. H., \& Yahya, K. K. (2017). Perceived Career Development Practice And Performance Of Employees: An Empirical Study In The Enforcement Organization. Journal of Global Business and Social Entrepreneurship (GBSE), 1(4), 54-61.

Motowidlo, S. J., \& Van Scotter, J. R. (1994). Evidence That Task Performance Should Be Distinguished From Contextual Performance. Journal Of Applied Psychology, 79(4), 475-480.

Mugaa, L. G., Guyo, W., \& Odhiambo, R. (2018). Influence of Career Progression on Employee Performance in Large Commercial Banks in Nairobi City County in Kenya. Journal of Entrepreneurship \& Project Management, 2(2), 1-19.

Mwashila, H. M. (2018). The Influence of Career Development on Academic Staff Performance In Kenyan Public Universities In Coast Region. (Master of Business Administration MBA), Technical University of Mombasa.

Nwuche, C. A., \& Awa, H. O. (2011). Career Planning And Development: The Realities In Nigerian Organizations. International Business and Management, 2(2), $117-127$.

Oduma, C., \& Were, S. (2014). Influence of Career Development On Employee Performance In The Public University, A Case Of Kenyatta University. International Journal of Social Sciences Management and Entrepreneurship, 1(2), 1-16.

Patrick, H. A., \& Kumar, A. (2011). Career Management, Employee Development and Performance in Indian Information Technology Organizations. Business Management Dynamics, 1(5), 24-31.

Pynes, J. E. (2009). Human Resources Management For Public And Nonprofit Organizations: A Strategic Approach (3rd ed.). San Francisco: Jossey-Bass Rhoades, L., \& Eisenberger, R. (2002). Perceived Organizational Support: A Review Of The Literature. Journal Of Applied Psychology, 87(4), 698-714.

Ringle, C. M., Wende, S., \& Will, S. (2005). SmartPLS 2.0 (M3) Beta: University of Hamburg, Hamburg. Retrieved from http:/www.smartpls.de/forum/index.php.

Saleem, S., \& Amin, S. (2013). The Impact of Organizational Support for Career Development and Supervisory Support on Employee Performance: An Empirical Study from Pakistani Academic Sector. European Journal of Business and Management, 5(5), 194-207. 
Shahzad, K., Bashir, S., \& Ramay, M. I. (2008). Impact of HR Practices On Perceived Performance Of University Teachers In Pakistan. International Review Of Business Research Papers, 4(2), 302-315.

Sonnentag, S., Volmer, J., \& Spychala, A. (2008). Job performance. In J. Barling, S. R. Clegg \& C. L. Cooper (Eds.), The Sage Handbook Of Organizational Behavior 1, 427-447. London: SAGE Publication Inc.

Suleiman, W. (2013). A Study of Causes of Poor Attitude to Work among workers of both Public and Private Sectors Organizations in Bauchi State-Nigeria. International Journal of Academic Research in Business and Social Sciences, 3(7), 143-152.

Tessema, T. M., \& Soeters, J. L. (2006). Challenges and Prospects Of HRM In Developing Countries: Testing The HRM-Performance Link In The Eritrean Civil Service. The International Journal of Human Resource Management, 17(1), 86-105.

Tiwari, P. (2011). Impact of Selected HRM Practices on Perceived Employee Performance: An Empirical Study. Global Management Journal, 3(1/2), 37-43.

Tsui, A. S., Pearce, J. L., Porter, L. W., \& Tripoli, A. M. (1997). Alternative Approaches To The Employee-Organization Relationship: Does Investment In Employees Pay Off? Academy of Management Journal, 40(5), 1089-1121.

Van Scotter, J. R. (2000). Relationships of Task Performance And Contextual Performance With Turnover, Job Satisfaction, And Affective Commitment. Human Resource Management Review, 10(1), 79-95.

Zia-ur-Rehman, M., Faisal, H., \& Khan, R. A. (2015). In Public Sector Organizations, how the Performance of Employees is influenced by the HR PracticesAnalyzing the Perspective. Journal of Managerial Sciences , IX(1), 50. 